\title{
PEMBANGUNAN DAN PARTISIPASI MASYARAKAT
}

\author{
Oleh: Djihad Hisyam \\ djihad_hisyam@uny.ac.id
}

\section{Abstrak}

Pembangunan pada dasarnya merupakan suatu proses yang dilakukan secara sadar dan berencana untuk membuat suatu perubahan dari keadaan sebelumnya yang kurang baik menjadi keadaan tertentu yang lebih baik. Untuk merealisir pembangunan diperlukan adanya partisipasi masyarakat. Karena manusia sebagai obyek dan sekaligus subyek pembangunan. Partisipasi masyarakat dapat digerakkan dengan beberapa cara, antara lain dengan menyesuaikan apa yang menjadi kebutuhan masyarakat secara nyata, kegiatan tersebut dapat dijadikan stimulan bagi masyarakat untuk timbulnya respons sebagaimana yang dikehendaki, dan dapat dijadikan sebagai motivasi bagi masyarakat yang bersangkutan untuk menciptakan tingkah laku yang dikehendaki.

\section{Pendahuluan}

Bagi negara-negara sedang berkembang, pembangunan dipandang sebagai suatu cara yang terbaik untuk mengatasi adanya berbagai macam kendala seperti: keterbelakangan, kemelaratan, kebodohan dan kehancuran sebagai akibat adanya penjajahan maupun peperangan. Oleh karena itu pembangunan selalu menjadi komitmen mereka yang terus diperjuangkan untuk merubah harkat martabat bangsa. Pembangunan sebagai suatu proses perubahan yang terencana, akan mampu menggeser sendi-sendi kehidupan yang kurang baik menjadi lebih baik lagi. Dalam hal ini pembangunan dianggap seba- gai senjata pamungkas yang paling mujarab untuk mengatasi segala kekurangan dan ketimpangan. Karenanya, tidak mustahil kalau pembangunan dijadikan sebagai spririt kehidupan dan diangkat sebagai slogan dan semboyan perjuangan. Bahkan dalam forum-forum pertemuan ilmiah, pembangunan tidak jarang dijadikan sebagai thema sentral pembicaraan dan pembahasan.

Pembangunan, secara konseptual mempunyai dimensi dan cakupan arti yang amat luas bahkan nyaris dikacaukan dengan istilahistilah lain seperti: modernisasi, westernisasi, industrialisasi, mekanisme, rekonstruksi ekonomi, pembaharuan. Khusus untuk memahami 
pengertian pembangunan secara definitif, Bjom Hettne (1982) mengatakan bahwa tidaklah mungkin ada satu definisi yang tetap dan pasti mengenai pembangunan. Yang ada hanyalah saran-saran mengenai apa yang harus ditunjukkan oleh pembangunan dalam konteks tertentu. Dan pembangunan harus merupakan konsep yang terbuka ujungujungnya, untuk mendefinisikan kembali terus menerus sejalan dengan semakin mendalamnya pengertian kita mengenai proses pembangunan, dan sejalan dengan timbulnya masalah-masalah baru yang harus dipecahkan oleh pembangunan (1982: 9).

Pendapat Bjom Hettne tersebut dapat difahami, sebab pembangunan memang bukan merupakan suatu konsep yang statis tapi dinamis. Bahkan pembangunan merupakan suatu orientasi dan kegiatan usaha yang dilakukan secara terus menerus, sebagaimana yang dirumuskan oleh United Nations "Development is not a static concept. It is continously changing" (1973).

Soul M. Katz sebagaimana dikutip Moeljarto Tjokrowinoto (1977 :1) merumuskan pembangunan sebagai :

"Suatu perubahan yang luas dari masyarakat, dari suatu keadaan kehidupan bangsa ke keadaan lain yang lebih bernilai (a major societal change from one state of national being to another more valued state) ${ }^{n}$
Dengan rumusan yang lain, Sondang P. Siagian (1976: 2) mengartikan pembangunan sebagai "suatu usaha atau rangkaian usaha pertumbuhan dan perubahan yang berencana yang dilakukan secara sadar oleh suatu bangsa, negera dan pemerintah menuju modernitas dalam rangka pembinaan bangsa"

Berdasarkan beberapa pendapat di atas, pembangunan merupakan suatu proses dan usaha untuk membuat perubahan masyarakat dari suatu keadaan tertentu ke keadaan lain yang lebih bernilai. Dengan bobot sasaran hasil pembangunan yang seperti itu, pembangunan pada akhirnya akan dapat digunakan sebagai pengendali masa depan yang mengandung beberapa implikasi :

1. Kemampuan (capacity)

2. Kebersamaan (equity) atau keadilan sosial

3. Kekuasaan (empowerment)

4. Ketahanan atau kemandirian (sustainability)

5. Kesaling-tergantungan (interndependence) (Taliziduhu Ndraha, $1990: 35-36$ ).

Salah satu segi yang perlu diperhatikan agar pembangunan dapat menjangkau sasaran perubahan keadaan yang lebih baik dan dapat digunakan sebagai pengendali masa depan, di dalam melaksanakan pembangunan itu perlu sekali memperhatikan segi manusianya. Mengapa ? Karena dalam arti proses, 
pembangunan menyangkut makna bahwa manusia adalah obyek pembangunan dan sekaligus subyek pembangunan. Sebagai subyek pembangunan manusia harus diperhitungkan, sebab dia punya nilai dan potensi yang luar biasa. Oleh karena itu dalam pembangunan perlu mengajak subyek tadi untuk ikut berpartisipasi aktif dalam pembangunan (Pasaribu, IL. Dan Simanjuntak, B. 1986:62). Bahkan Miftah Thoha menempatkan unsur manusia itu sebagai "a new significance element" sebab sasaran pembangunan juga ingin menjangkau pertumbuhan ekonomi, dimana kebahagiaan manusia harus diperhitungkan (tanpa tahun : 2). Suatu kenyataan menunjukkan bahwa peranan dan kemampuan rakyat terhadap pembangunan amat besar. Mereka merupakan suatu resource pembangunan yang amat menakjubkan, tapi potensi tersebut kadang masih terasa tertutupi oleh kabut tebal, mereka menjadi beku tanpa makna. Pancaran-pancaran pemikiran mereka belum bisa terbuka, atmosfir berpikir mereka ada pada ruang yang pada gema. Akhimya, nuansa-nuansa pemikiran mereka brilian menjadi hanyut tanpa suara. Maka lahirlah kebudayaan diam yang amat menakutkan bagi pertumbuhan demokrasi. Namun bagaimanapun adanya, manusia sebagai subyek pembangunan harus mendapatkan tempat yang pertama dan utama dalam pembangunan.
Sebagaimana Bryant mengatakan bahwa peran serta rakyat merupakan bagian dari proses dan definisi pembangunan (1987 : 268).

Untuk memberikan gambaran yang jelas mengenai partisipasi masyarakat, dalam tulisan ini secara berturut-turut akan dibahas mengenai : pengertian dan jenis partisipasi, mengapa pembangunan memerlukan partisipasi, beberapa cara untuk menggerakkan partisipasi dan beberapa hambatan di dalam melaksanakan partisipasi serta usahausaha pengatasannya.

\section{Pengertian dan Jenis Partisipasi}

Sebelum dijelaskan mengenai pengertian partisipasi, ada baiknya kalau diketahui terlebih dahulu kapan sebenamya istilah partisipasi itu muncul ? Santoso S. Hamijoyo dan A. Iskandar mengatakan: "Ajakan kepada masyarakat untuk berpartisipasi sesungguhnya bukan barang baru. Dengan nama dan fokus yang berbeda, ajakan itu sering kita dengar sebelumnya. Kita ingat ajakan agar rakyat ikut dalam Gerakan Hidup Baru, Gerakan Kebersihan, Gerakan Pemberantasan Buta Huruf, Gerakan Pagar Betis, Gerakan Menabung, Gerakan Keluarga Berencana, dan masih banyak lagi" (1974 : 345).

Dengan persepsi yang berbeda, ada yang berpendapat bahwa isu partisipasi dalam pembangunan itu mulai populer dan muncul 
pertama kali adalah dalam masyarakat di negara-negara yang sudah maju. Partisipasi muncul bersamaan dan bergandengan dengan pertumbuhan pendidikan, tumbuhnya institusi demokrasi dan menyebarnya komunikasi (Miftah Thoha, tth. : 5).

Kemudian apa yang dimaksud dengan partisipasi? Secara sederhana partisipasi dapat dikatakan sebagai "pengambilan bagian dalam kegiatan bersama" (Jnanabrota Bhattacharyya dalam Taliziduhu Ndraha, 1990 : 102). Sedangkan Mubyarto dalam strategi Pembangunan Pedesaan merumuskan partisipasi sebagai "kesediaan untuk membantu berhasilnya setiap program sesuai kemampuan setiap orang tanpa berarti mengorbankan kepentingan diri sendiri" (1984:35). Istilah partisipasi ini kadang disebut dengan peran serta sebagaimana Coralie Bryant dan Louise G. White mengatakan peran serta adalah kesadaran mengenai konstribusi yang dapat diberikan oleh pihakpihak lain untuk suatu kegiatan (1987 : 268). Pendapat lain yang lebih jelas adalah dari Davis yang dikutip Taliziduhu Ndraha, bahwa Keterlibatan kelompok atau masyarakat sebagai suatu kesatuan, dan dapat disebut partisipasi kolektif, sedangkan keterlibatan individual dalam kegiatan kelompok dapat disebut partisipasi individual (1990 : 102).
Dari beberapa pendapat tersebut, dapatlah dikemukakan bahwa sasaran utama dari partisipasi adalah timbulnya keikutsertaan aktif dari masyarakat dalam pembangunan. Mereka secara langsung atau tidak langsung mengambil bagian dalam setiap kegiatan pembangunan. Pemahaman terhadap makna partisipasi ini akan lebih jelas kalau dilihat jenis atau macamnya sumbangan yang diberikan oleh orang atau kelompok yang berpartisipasi. Macam atau jenis partisipasi itu meliputi :

a. Partisipasi buah fikiran.

b. Partisipasi tenaga.

c. Partisipasi harta benda.

d. Partisipasi ketrampilan dan kemahiran.

e. Partisipasi sosial (1974: 349 ).

Partisipasi buah fikiran merupakan partisipasi dalam bentuk sumbangan fikiran, pengalaman dan pengetahuan. Jenis partisipasi ini sudah banyak dikenal dalam masyarakat kita, dan sudah melembaga seperti: anjangsana, rapat desa, diskusi, seminar, simposium, workshop, lokakarya, rapat kerja, musyawarah. Bahkan di kalangan orang-orang Cina perantauan dikenal istilah "kongkow" dan "kongsi" yang dilaksanakannya secara dinamis, menjamin diperolehnya keterangan segar mengenai perkembangan ekonomi praktis, yang merupakan pangkal tolak menuju penguasaan ekonomi. 
Partisipasi tenaga, merupakan partisipasi dalam bentuk penyerahan, yang dalam masyarakat kita juga sudah melembaga seperti : puraga (wajib sumbang tenaga bagi pemilik sawah kanomeran terhadap pekerjaan desa), gotong royong. Bahkan ada partisipasi sukarela yang sampai sekarang tetap ada yaitu : warga desa gotong royong mendirikan rumah, membuat jalan, menyelenggarakan peralatan, merawat kematian, dan sebagainya.

Partisipasi harga benda, merupakan partisipasi dalam bentuk penyerahan harta benda secara suka rela seperti : adanya lumbung desa, seredan (partisipasi hasil bumi untuk keperluan sewaktu-waktu yang mendadak), dompet dhu'afa', dompet Merapi (sumbangan harta lewat majalah atau surat kabar).

Partisipasi keterampilan dan kemahiran, merupakan partisipasi dalam bentuk penyerahan atau pemberian ketrampilan dalam bentuk penyerahan atau pemberian ketrampilan atau keahlian tertentu. Dalam konteks ini seperti yang terdapat di Irian Jaya, dimana setiap suku yang memiliki ketrampilan mengukir yang khas untuk tiap suku, diwajibkan mengukir tiang-tiang pokok rumah kepala adat yang menguasai sukusuku di sekitamya.

Begitu pula partisipasi kemahiran seni ukir dalam pembuatan rumah bujang di daerah Asmat yang terkenal dengan ukir-ukirannya yang primitif itu. Kalau di tempat lain ada partisipasi ketrampilan atau keahlian untuk membuat makanan, dekorasi, membuat jamu, dan sebagainya.

Partisipasi sosial, merupakan partisipasi dalam bentuk kedekatan hati, yang sudah melemtaga seperti arisan, koperasi, simpan pinjam dengan pemberian sekedar uang khas.

Berbagai macam jenis atau bentuk partisipasi sebagaimana telah diuraikan diharapkan dapat membantu memberi kemudahan di dalam memahami partisipasi.

\section{Mengapa Pembangunan Memer- lukan Partisipasi}

Pembangunan pada dasamya merupakan kegiatan yang bersifat kompleks dan menyeluruh, menyangkut berbagai aspek dan kepentingan orang banyak. Karena itu pembangunan tidaklah mungkin hanya dilakukan oleh pemerintah saja, akan tetapi membutuhkan keikutsertaan masyarakat. Hal ini dilakukan bukan saja agar masyarakat dapat menikmati keuntungan dari hasil pembangunan, namun agar masyarakat dapat ikut serta menyumbangkan peran aktifnya dalam setiap langkah dari program pembangunan, mulai dari perencanaan, pelaksanaan, monitoring dan evaluasi.

Michael Carnea dalam hubungannya dengan keberhasilan program partisipasi di Mexico 
mengatakan bahwa: Partisipasi Rakyat (beneficianies) merupakan satusatunya jalan yang harus dilalui itu bukan alasan-alasan politik dan ideologi, akan tetapi yang utama untuk memperoleh efisiensi dan untuk alasan-alasan yang bersifat ekonomi dan teknis (Michael Cemea dalam Miftah Thoha, tth.: 8).

Jadi, pembangunan tetap membutuhkan adanya dukungan dari bawah atau partisipasi masyarakat, agar sasaran pembangunan dapat berhasil. Dalam hal ini ada beberapa keuntungan yang dapat diperoleh dengan adanya partisipasi dalam proses pembangunan :

1. Banyak proyek pembangunan yang tidak bisa keluar dari lilitan persoalan jika masyarakat atau rakyat itu tidak diikut sertakan atau terlibat dalam proses pemibangunan. Mengapa ? Mereka (orang-orang yang ada di daerah tempat yang akan dibangurı) lebih mengetahui persoalannya sendiri, dibandingkan dengan para perencana pembangunan yang tempatnya jauh dengan lokasi. Karena itu partisipasi sumberdaya lokal dapat dipergunakan untuk meredam dan mengatasi masalahmasalah yang timbul.

2. Dengan partisipasi para perencana dilengkapi dengan informasi yang amat berharga dan tidak dapat diperoleh dengan cara lain.
3. Rakyat akan menerima perubahan-perubahan apabila mereka diajak merancang untuk menghasilkan perubahan itu. Bahkan sebagaimana yang disarankan Bank Dunia, partisipasi itu diharapkan dapat dimulai sejak dari saat merancang, mengkonstruksi, melaksanakan sampai mengevaluasi.

4. Beberapa studi telah membuktikan bahwa dengan partisipasi akan banyak menghemat biaya dengan cara memobilisasikan tenaga kerja tak terpakai (unused labour) dan sumber daya lokal lainnya.

5. Telah banyak diketahui bahwa dengan partisipasi masyarakat itu memberikan manfaat yang cukup besar di dalam ikut menyelesaikan suatu proyek.

6. Untuk memantau suatu kegiatan proyek, diperlukan datang ke lokasi atau lapangan. Dalam hal ini akan lebih bermanfaat dan efisien jika masyarakat setempat ikut dilibatkan. Mereka akan dapat memonitor diri mereka sendiri, mengawasi diri sendiri dan mereka akan mempunyai rasa ikut bertanggung jawab untuk menjaganya dan bekerja sebaik-baiknya.

7. Partisipasi dapat dikatakan sebagai suatu proses pendidikan. Dengan partisipasi rakyat dididik untuk merasakan ikut memiliki, menjaga dan mengembalikan 
setiap program yang dibuat bersama (Miftah Thoha, tth.: 810).

Demikianlah perlunya partisipasi dan beberapa keuntungan yang dapat diambil dengan adanya partisipasi dalam melaksanakan pembangunan.

\section{Beberapa Cara untuk Mengge-} rakkan Partisipasi

Partisipasi dalam pembangunan memang sangat diperlukan, namun untuk menggerakkan, melaksanakan tidaklah mudah. Ada beberapa prasyarat yang perlu diperhatikan :

1. Dalam masyarakat tersebut tumbuh rasa senasib sepenanggungan, ketergantungan dan keterikatan (sense of belonging dan sense of committment).

2. Ada keterikatan terhadap tujuan hidup yang diidam-idamkannya dan ada kemauan kuat untuk mencapainya.

3. Mempunyai kemahiran untuk beradaptasi atau menyesuaikan dengan perubahan keadaan.

4. Adanya prakarsawan, yaitu orang yang mau memulai melakukan perubahan.

5. Terdapat iklim partisipasi yang kondusif, antara lain :

a. Kedaulatan perorangan setiap peserta tetap dihormati oleh peseria lain yang terlibat dalam jaringan partisipasi. b. Menghormati wewenang yang telah dilimpahkan kepada setiap peserta atau sekelompok peserta.

c. Wewenang yang lebih tinggi tidak dipergunakan untuk mempengaruhi keputusan yang secara resmi telah dilimpahkan kepada peserta.

d. Orang yang akan terpengaruh (terkena) oleh keputusan mengenai partisipasi sebaiknya dilibatkan dalam pengambilan keputusan.

e. Tertanamnya perasaan dan pengertian bahwa keikut sertaannya seseorang atau sekelompok peserta mempunyai arti yang relevan bagi dirinya dan masyarakat sekitanya.

f. Adanya komunikasi yang mendasarkan pada tenggang rasa.

6. Adanya pembangunan (Santoso S. Hamijoyo dan A. Iskandar, 1974).

Kemudian bagaimana cara menggerakkan partisipasi ? Ada beberapa pendapat mengenai cara menggerakkan partisipasi :

a. Disesuaikan dengan kebutuhan masyarakat yang nyata (felt need).

b. Kegiatan yang dilakukan itu dapat dijadikan sebagai stimulasi terhadap masyarakat dan berfungsi mendorong timbulnya 
respons sebagaimana yang dikehendaki.

c. Kegiatan yang dilakukan itu dapat dijadikan sebagai motivasi terhadap masyarakat yang dapat berfungsi untuk membangkitkan tingkah laku (behavior) yang dikehendaki secara berlanjut (Narain, Mednick, Bryant dalam Taliziduhu Ndraha, 1990).

Selain menggunakan cara-cara tersebut, partisipasi dapat digerakkan melalui :

a. Proyek pembangunan desa yang dirancang secara sederhana dan mudah dikelola oleh masyarakat.

b. Lewat organisasi dan lembaga kemasyarakatan yang mampu menggerakkan dan menyalurkan aspirasi masyarakat.

c. Peningkatan peran masyarakat dalam pembangunan (Bryant dalam Taliziduhu Ndraha, 1990 : 104-105).

Demikianlah beberapa cara yang dapat dilakukan atau ditempuh untuk menggerakkan partisipasi masyarakat.

Hambatan-hambatan Dalam Melaksanakan Partisipasi dan Usahausaha Pengatasannya

Pelaksanaan partisipasi masyarakat ternyata tidaklah mudah, banyak sekali hambatan-hambatannya, yang secara garis besar dapat dibagi dalam dua macam hambatan :
1. Hambatan internal, yang berupa hambatan sosio kultural (sociocultural constraints).

2. Hambatan eksternal, yaitu hambatan dari birokrasi pemerintah (Miftah Thoha, th.: 11-17).

Hambatan internal, merupakan hambatan dari dalam masyarakat sendin, yang merupakan keengganan sebagian besar warya masyarakat untuk terlibat langsung dalam suatu kegiatan. Hal ini disebabkan karena keadaan sosio kultural mereka belum memungkinkan untuk secara aktif menyuarakan, menyampaikan dan mengutarakan keinginan-keinginan mereka. Sementara mereka lebih memilih diam, mereka sudah merasa puas dengan keadaan di sekitar lingkungan mereka. Hambatan sosio kultural ini bukanlah merupakan hambatan yang fatal, sebab hambatan ini lebih banyak bersifat conservatism. Untuk mengatasi hambatan internal ini mereka harus lebih banyak diberikan masukan informasi-informasi baru yang positif yang bersifat membangun. Mereka harus dikenalkan dengan penemuan dan perkembangan baru di daerah lain, yang nantinya akan mampu membuka cakrawala berpikir mereka. Kecuali itu, kadang mereka memang mempunyai tingkat kesadaran yang rendah karena adanya beberapa keterbatasan. Misalnya: rendahnya pendidikan, rendahnya tingkat sosial ekonomi, kurangnya 
sarana dan prasarana. Langkah pengatasannya bagi mereka yang serba kekurangan adalah dengan mengentaskan dari segala keterbelakangan tersebut.

Hambatan eksternal, adalah hambatan dari perilaku para birokrat, perencana, dimana mereka banyak yang mengambil jarak dengan masyarakat sehingga kurang mengenal lapangan. Kecuali itu juga sistemnya itu sendiri yang kadang lebih menekankan perencanaan dari atas (top-down) atau strategi center down, kurang memperhatikan masyarakat bawah. Akibatnya pembangunan yang dilakukan kadang tidak realistis dan mengalami stagnasi. Hal ini sesuai dengan yang dikeluhkan oleh Paulus Hidayat: Bagaimana mungkin masyarakat dapat berperan serta dalam merencanakan suatu program (pembangunan) apabila program ini merupakan suatu paket yang disusun, dijalankan dan diurus oleh tingkat nasional (1988: 357 ).

Sebagai upaya pengatasannya, tentunya para birokrat pelaksana pembangunan harus menjauhkan diri dari perilaku mengurung diri di kantor, akan tetapi harus terjun ke lapangan apa yang dikemukakan oleh Kartasapoetra : Para birokrat hendaknya turun ke bawah untuk mendapatkan informasi dari dua pihak, yaitu dari para aparatur pelaksana dan dari pihak masyarakat. Dengan demikian dapat diperoleh informasi yang benar uniuk dijadikan bahan pertimbangan guna mengadakan perbaikan-perbaikan pelayanan pada masyarakat (1989: 21).

\section{Penutup}

Dari uraian di atas, dapatlah disimpulkan bahwa pembangunan mempunyai kaitan yang sangat erat dengan partisipasi masyarakat, sebab pembangunan tidak akan dapat hanya dilakukan oleh pemerintah saja.

Akhirnya penulis menyadari bahwa tulisan ini masih jauh dari memuaskan. Untuk itu kritik dan saran yang sifatnya membangun sangat penulis harapkan.

\section{Daftar Pustaka}

Bryant, Carolie and Louise G. White. 1987. Manajemen Pembangunan Untuk Negara Berkembang, Jakarta: LP3ES.

Hamijoyo, Santoso, S. dan A. Iskandar. 1974. Partisipasi Masyarakat, Seminar Pembangunan Kabupaten Bandung Dalam Sosiologi Pembangunan, Bandung.

Hettne, Bjom. 1995. Ironi Pembangunan Di Negara Berkembang, Terjemahan : Isnu Martoyo, Jakarta : Sinar Harapan.

Hidayat, Paulus. 1998. Peran Serta Dan Bawah Dalam BirokrasiBirokrasi Yang Hirarkis: Dilema Tak Terpecahkan Dalam 
Perawatan Kesehatan Primer $\mathrm{Di}$ Indonesia, Editor Arief Budiman dan Ph. Quarles Van Ufford, Krisis Tersembunyi Dalam Pembangunan: Birokrasi-Birokrasi Dalam Pembangunan, Jakarta : PT. Gramedia.

Kartasapoetra, G. 1989. Debirokratisasi dan Deregulasi, Jakarta : Bina Aksara.

Mubyarto. 1984. Strategi Pembangunan Pedesaan, Yogyakarta : P3PK-UGM.

Ndraha, Taliziduhu. 1990. Pembangunan Masyarakat Mempersiapkan Masyarakat Tinggal Landas, Jakarta : Rineka Cipta.

Pasaribu, I. L. dan Simanjuntak, B. 1986. Sosiologi Pembangunan, Bandung: Tarsito.

Siagian, Sondang, P. 1976. Administrasi Pembangunan, Jakarta : Gunung Agung.

Thoha, Niftah. tanpa tahun. Birokrasi Pembangunan dan Partisipasi Rakyat, Makalah Lepas.

Tjokrowinoto, Moeljarto. 1977. Peranan Kebudayaan Politik dan Kebudayaan Administrasi di Dalam Pembangunan Masyarakat Desa, Yogyakarta : Bulletin BPA-UGM.

United Nations. 1973. Development Administration : Current Approaches and Trends in Public Administration for National Development : New York.
Abu Syuqqah, 'Abd al-Halim. 1997. Tahrir al-Mar'ah fi 'Ashr alRisalah. Alih bahasa oleh Chairul Halim. Jakarta: Gema Insani Press. Cet. I. Jilid 2.

\section{Biodata Penulis}

Djihad Hisyam, adalah staf pengajar pada Program Studi Pendidikan Administrasi Perkantoran Fakultas IImu Sosial Universitas Negeri Yogyakarta. Lulus PPs Universitas $\mathrm{Ne}$ geri Yogyakarta pada tahun 1999. 